\title{
Evaluation of a Bovine Concentrated Lactoserum for Preventing Neonatal Diarrhoea in Belgian Blue Calves
}

\author{
S. Vandeputte ${ }^{*}, 1$ J. Detilleux ${ }^{2}$, S. Carel ${ }^{3}$, B. Bradfer ${ }^{4}$, H. Guyot ${ }^{1}$ and F. Rollin ${ }^{1}$ \\ ${ }^{I}$ Clinic for Ruminants, Clinical Department of Production Animals, University of Liege, Faculty of Veterinary Medicine, \\ Boulevard de Colonster, 20, B42, B-4000 Liege, Belgium \\ ${ }^{2}$ Department of Animal Production, University of Liege, Faculty of Veterinary Medicine, Boulevard de Colonster, 20, \\ B43, B-4000 Liege, Belgium \\ ${ }^{3}$ Biokema, CH-1023 Lausanne, Switzerland \\ ${ }^{4}$ Fendigo sa/nv, 1160 Brussels, Belgium
}

\begin{abstract}
The purpose of this study was to evaluate, under field conditions, the efficacy of an european registered bovine concentrated lactoserum (Locatim) in 3 farms with neonatal diarrhoea in calves. A total of 117 healthy Belgian Blue (BB) calves were allocated in 2 groups. Two thirds of the calves received Locatim orally immediately after birth and maternal colostrum one hour later (treated group), while control calves only received maternal colostrum. Every day during 14 days, mental status, faeces consistency, suckling reflex and hydration status of each calf were monitored. Individual blood samples were assessed for passive transfer and specific Escherichia coli antibodies against strains F5, CS31A, F17 and F41. Faecal samples from diarrheic and non diarrheic calves were analysed for rotavirus, bovine coronavirus, Cryptosporidium parvum and Escherichia coli F5. Locatim had no significant effect on the onset, duration and incidence of diarrhoea. The mean serum IgG concentration of $23.1 \pm 7.8 \mathrm{mg} / \mathrm{ml}$ indicates a good IgG transfer. Only the CS31A strain titer was significantly higher in the treated group. The major identified causative agent of diarrhoea was C. parvum. In conclusion, Locatim only has a slight effect when IgG transfer is optimal, but could be justified when specific antibodies lacking in colostrum are needed.
\end{abstract}

Keywords: Colostrum, specific antibodies, enteropathogens, failure of passive transfer.

\section{INTRODUCTION}

The first week of life is a critical period for the newborn calf and is generally associated with a mortality rate of $10 \%$ [1]. Diarrhoea is one of the major causes of mortality in newborn calves. The incidence of diarrhoea in calves under one month ranges between 15 to $20 \%$ [2-4], the greatest risk occurring during the first two weeks of life. Neonatal diarrhoea is an important source of economic losses for the farmer: the cost of prevention and treatment was estimated at approximately 33 US dollars per calf and per year [5]. The onset of diarrhoea is multifactorial and influenced by various environmental, managemental, nutritional and infectious factors. Main enteropathogens in neonatal calves are rotavirus, bovine coronavirus, Escherichia coli and Cryptosporidium parvum (C. parvum) [6]. Given that calves are born agammaglobulinemic, they are very receptive to neonatal infections. Therefore, the administration of an adequate quantity of immunoglobulins $\mathrm{G}(\mathrm{IgG})$ within the first 24 hours of life is essential. Moreover, the level of immunity of the newborn plays an important role on the incidence and severity of diarrhoea. The maternal colostrum is the first source of $\operatorname{IgG}$ to newborn calves. The total

*Address correspondence to this author at the University of Liege, Faculty of Veterinary Medicine, Clinical Department of Production Animals, Clinic for Ruminants, 20, Boulevard de Colonster, 4000, Liege, Belgium; Tel: +3243664020; Fax: +3243664024; E-mail: svandeputte@ulg.ac.be amount of IgG absorbed essentially depends on the volume of colostrum, the $\operatorname{IgG}$ concentration of the ingested colostrum, the time between birth and the first feeding and the calf's health status at birth [7]. An inadequate uptake of colostrum leads to a partial or a total failure of the passive transfer (FPT), which increases morbidity and mortality rates in neonatal calves [8]. Nevertheless, colostrum quality not only relates to $\operatorname{IgG}$ concentration but also to $\mathrm{IgG}$ diversity which essentially reflects previous exposition of the cow to various pathogens. Without sufficient exposure, primiparous cows frequently produce a colostrum of lower or inadequate IgG diversity. Moreover, different strains of one pathogen, like the F5, F41, F17 and CS31A strains of the enterotoxigenic E. coli, can simultaneously be involved and therefore, antibodies against all these strains are required in order to ensure a complete protection [9]. Maternal vaccination against different strains of pathogens is one suitable preventive method to improve the diversity of IgG. However, under field conditions, maternal vaccination is not always possible. To enhance the poor protection provided by a colostrum with low $\operatorname{IgG}$ level or without specific antibodies, the use of a colostrum supplement has been proposed as a source of exogenous antibodies for calves.

The objectives of this study were to evaluate, under field conditions, the efficacy of the oral administration of a single dose of Locatim, a bovine concentrated lactoserum registered for the prevention of neonatal diarrhoea, and to 
measure the effect of this administration on the calves' serum total $\mathrm{IgG}$ and specific IgG concentrations.

\section{MATERIALS AND METHODOLOGY}

\section{Study Protocol}

The study protocol was approved by the ethics committee of the University of Liege (ethics file $\mathrm{n}^{\circ 512}$ ). Animals used were newborn calves of the hypermuscled Belgian Blue (BB) breed from three different farms presenting neonatal diarrhoea problems. All calves were born by $\mathrm{C}$-section and had to be clinically healthy for inclusion in the protocol. Each selected calf was monitored during the first fourteen days of life (duration of the study). Farms were visited once a week at a regular interval during 17 weeks. Immediately after birth, calves were alternately allocated in 2 groups (treated or control calves). Sequentially, 2 calves orally received $60 \mathrm{ml}$ of an european registered bovine concentrated lactoserum $\left(\mathrm{N}^{\circ} \mathrm{EU} / 2 / 99 / 011 / 001\right)$ with a certified antibody titer $\geq 2.8 \log _{10}$ for $E$. coli F5; $\geq 3.1 \log _{10}$ for $E$. coli $\mathrm{CS} 31 \mathrm{~A} ; \geq 3.2 \log _{10}$ for $E$. coli $\mathrm{F} 17 ; \geq 3.2 \log _{10}$ for E. coli $\mathrm{F} 41 ; \geq 3.2 \log _{10}$ for rotavirus and $\geq 3.2 \log _{10}$ for bovine coronavirus (Locatim; Biokema; Switzerland) within the first hour of life. Each pair of treated calves was followed by one control calf. Calves received 4 litres of fresh maternal colostrum one hour after Locatim uptake and, for the control group, as soon as possible after birth. For each calf, mental status, faecal consistency (FC), suckling reflex (SR) and hydration status (HS) were monitored daily throughout the study, according to a scoring table (Table 1). A calf was considered diarrheic when the $\mathrm{FC}$ was $\geq 2$. No concurrent medication was administered to clinically healthy calves during the period of this study. When calves presented signs of a clinical disease (diarrhoea or other), a treatment was established by the farms' veterinarian.

\section{Farms and Animals}

One hundred seventeen calves, 65 females and 52 males were included in the study. A brief description of the 3 farms and the repartition of calves by farm are presented in Table 2.

\section{Data and Samples Collection}

The colostrum density was assessed at a temperature of $25^{\circ} \mathrm{C}$ with a colostrum densitometer (precision of $12.5 \mathrm{~g} / \mathrm{L}$ ). For each calf, blood samples were collected between days 3 and 8 after birth (depending on the fixed day of visit) by jugular venipuncture into evacuated serum tubes. Serum was separated by centrifugation (1,500 x g during 10 minutes), frozen at $-20^{\circ} \mathrm{C}$ and analysed blindly by the Biokema QC laboratory (Switzerland) by HPLC for the total IgG content and by microagglutination for the titration of specific IgG against F5, F17, F41 and CS31A E. coli strains. Faecal samples were collected from 28 diarrheic and 13 nondiarrheic calves directly from rectum and analysed with a BioX K071 kit (Bio-X Diagnostics, Belgium) for rotavirus, bovine coronavirus, E. coli K99/F5 and C. parvum.

Table 1. Clinical Scoring Evaluation of Calves for Mental Status, Suckling Reflex, Faecal Consistency and Hydration Status

\begin{tabular}{|c|c|c|c|c|c|}
\hline Score & 0 & 1 & 2 & 3 & 4 \\
\hline Mental Status & normal & depressed but standing & sternal recumbency & lateral recumbency & \\
\hline $\begin{array}{l}\text { Suckling } \\
\text { Reflex }\end{array}$ & $\begin{array}{l}\text { strong and } \\
\text { coordinated }\end{array}$ & weak but coordinated & disordered chewing & absent & \\
\hline $\begin{array}{c}\text { Faecal } \\
\text { Consistency }\end{array}$ & normal & semi-solid & liquid & aqueous and abundant & \\
\hline $\begin{array}{l}\text { Hydration } \\
\text { Status }\end{array}$ & normal & $\begin{array}{l}\text { - enophtalmus of 1-2 mm } \\
\text { - skin fold persisting } 3 \text { to } 4 \mathrm{sec} \text {. }\end{array}$ & $\begin{array}{l}\text { - enophtalmus of 3-5 mm } \\
\text { - skin fold persisting } 5 \mathrm{sec} .\end{array}$ & $\begin{array}{c}\text { - enophtalmus of } 6-7 \mathrm{~mm} \\
\text { - skin fold persisting } 6 \text { to } 10 \mathrm{sec} .\end{array}$ & $\begin{array}{l}\text { - enophtalmus } \geq 8 \mathrm{~mm} \\
\text { - persisting skin fold }\end{array}$ \\
\hline
\end{tabular}

Table 2. Description of the 3 Farms and Repartition of Calves by Farm

\begin{tabular}{|c|c|c|c|}
\hline & \multicolumn{3}{|c|}{ Farms } \\
\hline Number of calves & 44 & 21 & 52 \\
\hline Housing of calves & free calves behind dams & attached calves beside dams & $\begin{array}{c}\text { free calves allotted by } 12 / \text { stall or alone in an } \\
\text { individual box }\end{array}$ \\
\hline Reproduction & $\begin{array}{l}\text { artificial insemination and natural } \\
\text { breeding }\end{array}$ & natural breeding & $\begin{array}{l}\text { artificial insemination and embryo transfer on } \\
\text { Holstein Friesian (HF) heifers }\end{array}$ \\
\hline Vaccination & no & $\begin{array}{l}\text { against rotavirus, bovine } \\
\text { coronavirus and } E \text {. coli } \mathrm{F} 5 / \mathrm{F} 41\end{array}$ & no \\
\hline Mineral complementation & yes & yes & not for HF heifers \\
\hline
\end{tabular}




\section{Statistical Data Analysis}

All results were analysed using the program SAS (Statistical Analysis System, 6.03 Edition).

The animals were classified in 4 groups: with or without diarrhoea and treated or control. A chi-square test was used to test the differences in numbers between farms and between the four calf groups. A Fischer's Exact Test was used to test differences between farms and calf groups of the day of diarrhoea onset and the diarrhoea duration and results of coprological analysis. The General Linear Model (GLM) procedure was used to assess the effects of treatment (Locatim or control), FC (diarrheic or non diarrheic) and farms as well as the interaction between effects of farms and treatment, treatment and FC and farms and FC. All data are given as mean \pm standard deviation (S.D.) and differences were considered statistically significant at the $\mathrm{P}<0.05$ level.

\section{RESULTS}

\section{Clinical Scores}

The number of diarrheic calves was not significantly different between treated ( $\mathrm{n}=27$ calves $)$ and control $(\mathrm{n}=38$ calves) groups. The day of diarrhoea onset and its duration were significantly different between farms, with earlier diarrhoea appearing in farm $\mathrm{C}$ (day 3 ) and a shorter duration in farm B (1.2 \pm 0.5 days). The administration of Locatim had no significant effect on the time of onset or on the duration of diarrhoea, although a slightly shorter duration was observed in the treated group.

In comparison with farms $\mathrm{A}$ and $\mathrm{B}$, farm $\mathrm{C}$ had significantly more diarrheic calves presenting mental status and SR scores higher than 0 . No sign of dehydration was observed in the three farms. The mental status, SR and HS scores were not significantly different between treated and control groups.

\section{Faecal Samples}

C. parvum was the most prevalent enteropathogen found, present in 31 samples, followed by rotavirus present in 9 samples. Bovine coronavirus was detected in 4 samples of farm A and E. coli $\mathrm{F} 5$ in one sample of farm C. C. parvum was the only pathogen detected in farm B and was found significantly more often in faecal samples of diarrheic calves. A mixed infection involving two enteropathogens was found in $24 \%$ of all faecal samples and was observed in $32 \%$ of diarrheic and $8 \%$ of non diarrheic faecal samples. Most frequently, the mixed infection was a combination of C. parvum and rotavirus. Results of faecal samples analysis from diarrheic and non-diarrheic calves for rotavirus, bovine coronavirus, E. coli $\mathrm{F} 5$ and $C$. parvum are presented on Table 3.

\section{Colostrum Density, Serum IgG Concentration and Specific IgG Transfer}

Colostrum density and serum IgG concentration were not significantly different between farms nor between diarrheic and non-diarrheic calves. Mean colostrum density was $103 \pm$ $17 \mathrm{~g} / \mathrm{L}$, colostral density below $75 \mathrm{~g} / \mathrm{L}$ was observed in 5 primiparous $\mathrm{HF}$ cows from farm C. Mean serum $\operatorname{IgG}$ concentration was $23.1 \pm 7.8 \mathrm{mg} / \mathrm{ml}$. A total FPT was diagnosed in 24 calves: in 22 cases (20\%) the serum IgG was lower than $16 \mathrm{mg} / \mathrm{ml}$ and 2 cases $(2 \%)$ had less than 10 $\mathrm{mg} / \mathrm{ml}$. Only the CS31A E. coli titer was significantly higher for the treated group compared to the control group. No significant difference of serum IgG concentration and specific IgG transfer was found between diarrheic and non diarrheic calves. Colostrum density, serum IgG concentration and E. coli strains antibodies titers are presented in Table 4.

\section{DISCUSSION}

\section{Clinical Scores}

In the present study, the Locatim had no significant effect on the prevalence of diarrhoea in treated calves. The absence of effect can be explained on the one hand by the adequate immunity transfer in most of calves and, on the other hand, by the high prevalence of C. parvum in diarrheic calves. Adequate immunity transfer combined with good surveillance and early treatment of diarrheic calves accounts for the short duration of diarrhoea in all farms. In addition, the lesser duration of diarrhoea in farm B could be explained by a lower population density of calves and the vaccination of the dams, although the low number of diarrheic calves in this farm limits the interpretation of this result. In agreement with a previous report $[10,11]$, trace element deficiencies in pregnant cows are frequently associated with weaker calves at birth and with an increase of neonatal mortality and morbidity rates. The HF heifers on farm $\mathrm{C}$ were not given trace elements, which could partly explain the greater sensibility of calves to diarrhoea in this farm (earlier diarrhoea onset, higher number of diarrheic calves, more serious systemic repercussions observed in many diarrheic calves). In the three farms, the lesser severity of diarrhoea is confirmed by the absence of significant dehydration resulting from a reduced fluid loss via faeces.

Table 3. Results of Faecal Samples Analysis from Diarrheic and Non-Diarrheic Calves for Rotavirus, Bovine coronavirus, E. coli F5 and $C$. parvum

\begin{tabular}{|c|c|c|c|}
\hline Infectious Agent & $\begin{array}{c}\text { Number of Positive Faecal Samples from } \\
\text { Diarrheic Calves (n= 28) }\end{array}$ & $\begin{array}{c}\text { Number of Positive Faecal Samples from } \\
\text { Non-Diarrheic Calves (n= 13) }\end{array}$ & \begin{tabular}{c} 
Total \\
\hline \hline
\end{tabular} \\
\hline Rotavirus & 7 & 2 & 1 \\
\hline Bovine coronavirus & 3 & 0 & 4 \\
\hline E. coli F5 & 1 & 1 & 7 \\
\hline C. parvum & 24 & 31 \\
\hline
\end{tabular}


Table 4. Mean Colostrum Density, Serum IgG Concentration and E. coli Strains Antibodies Titers in the Three Farms for the Diarrheic, Non Diarrheic, Treated and Control Calves

\begin{tabular}{|c|c|c|c|c|c|c|c|}
\hline Farms & Categories & $\begin{array}{c}\text { Colostrum } \\
\text { Density }(\mathrm{g} / \mathrm{L})\end{array}$ & $\begin{array}{c}\text { Serum IgG } \\
\text { Concentration } \\
(\mathrm{mg} / \mathrm{ml})\end{array}$ & \multicolumn{4}{|c|}{ E. coli Strains Antibodies Titers (log (1/Dilution)) } \\
\hline \multirow{3}{*}{ A } & Diarrheic & $109( \pm 15)$ & $21.0( \pm 7.1)$ & $2.11( \pm 0.30)$ & $1.92( \pm 0.33)$ & $4.08( \pm 0.26)$ & $2.69( \pm 0.40)$ \\
\hline & Non diarrheic & $107( \pm 14)$ & $22.0( \pm 7.8)$ & $2.08( \pm 0.41)$ & $1.92( \pm 0.33)$ & $4.08( \pm 0.18)$ & $2.78( \pm 0.38)$ \\
\hline & Control & $112( \pm 13)$ & $19.7( \pm 6.7)$ & $2.10( \pm 0.31)$ & $1.70( \pm 0.19)$ & $4.11( \pm 0.19)$ & $2.68( \pm 0.30)$ \\
\hline \multirow{2}{*}{ B } & Diarrheic & $95( \pm 19)$ & $28.4( \pm 8.1)$ & $2.20( \pm 0.21)$ & $1.96( \pm 0.33)$ & $4.06( \pm 0.13)$ & $2.56( \pm 0.39)$ \\
\hline & Non diarrheic & $103( \pm 18)$ & $24.7( \pm 9.1)$ & $2.29( \pm 0.39)$ & $1.88( \pm 0.32)$ & $4.08( \pm 0.20)$ & $2.73( \pm 0.70)$ \\
\hline \multirow{4}{*}{$\mathrm{C}$} & Diarrheic & $99( \pm 18)$ & $21.4( \pm 6.1)$ & $2.19( \pm 0.23)$ & $1.77( \pm 0.24)$ & $4.04( \pm 0.24)$ & $2.74( \pm 0.37)$ \\
\hline & Non diarrheic & $100( \pm 17)$ & $26.8( \pm 8.8)$ & $2.24( \pm 0.27)$ & $1.87( \pm 0.30)$ & $4.11( \pm 0.22)$ & $2.71( \pm 0.24)$ \\
\hline & Treated & $100( \pm 17)$ & $22.2( \pm 6.1)$ & $2.19( \pm 0.22)$ & $1.90 *( \pm 0.27)$ & $4.09( \pm 0.26)$ & $2.76( \pm 0.36)$ \\
\hline & Control & $100( \pm 19)$ & $25.3( \pm 9.0)$ & $2.24( \pm 0.27)$ & $1.71( \pm 0.23)$ & $4.05( \pm 0.21)$ & $2.70( \pm 0.28)$ \\
\hline
\end{tabular}

$*$ Indicates a statistical significance $(\mathrm{p}<0.05)$.

\section{Faecal Samples}

C. parvum was detected in $76 \%$ of faecal samples, which is higher than the prevalence of 32 to $55 \%$ observed in diarrheic calves in other studies [12-15]. However, a large proportion of samples were provided by diarrheic calves in which the shedding of $C$. parvum is showed to be significantly higher [14, 16]. Rotavirus and bovine coronavirus were found in respectively $22 \%$ and $10 \%$ of faecal samples, which is lower than prevalence of respectively $32.5 \%$ and $13.6 \%$ described in diarrheic calves by [12] in Vendée. The adequate immune status of calves associated with a reduced excretion of enteropathogens probably plays an important role in this observation.

The prevalence of E. coli $\mathrm{F} 5$ is lower than that found in diarrheic calves by [17] $(11.9 \%)$ and by [13] $(12.5 \%)$ in Spain, by [18] (3\%) in southern Britain, by [15] $(5.5 \%)$ in Switzerland and even in Belgium in 2005 (11.2\%) (personal communication, ARSIA) but is in agreement with the prevalence of $2.6 \%$ found in Norway [14]. As for rotavirus and bovine coronavirus, the lower detection of E. coli F5 could be explained by an adequate transfer of the colostral immunity and a reduction of the infectious pressure related to the Locatim administration. In this study, mixed infections were more frequently detected in diarrheic calves and, according to $[13,15,17]$, the most common mixed infection was $C$. parvum-rotavirus. The low prevalence of the $E$. coli F5 strain and the absence of search for the F41, F17 and CS31A E. coli strains restrict the assessment of Locatim efficacy against colibacillosis diarrhoea.

\section{Colostrum Density}

The mean colostral density of $103 \pm 17 \mathrm{~g} / \mathrm{L}$ was above the common threshold value of $75 \mathrm{~g} / \mathrm{L}$ and reflects the fact that beef cows produce smaller amounts of more concentrated colostrum [19]. This adequate colostrum density provides more than $45 \mathrm{~g} / \mathrm{L}$ of $\mathrm{IgG}$ necessary for a minimal ingestion of $100 \mathrm{~g}$ of $\mathrm{IgG}$ recommended for adequate passive immunity transfer $[2,20]$. The lower colostrum density observed in $5 \mathrm{HF}$ primiparous could largely be related to the parity and breed of the cows $[8,21]$.

\section{IgG Serum Concentration}

The mean serum IgG concentration of $23.1 \pm 7.8 \mathrm{mg} / \mathrm{ml}$ was above threshold values of $10 \mathrm{mg} / \mathrm{ml} \mathrm{[22]} \mathrm{or} 16 \mathrm{mg} / \mathrm{ml}$ [23] classically used to diagnose a total FPT. The prevalence of total FPT observed in this study was lower than the $40 \%$ described in some reports [21] and could be related to a timely distribution of an adequate quantity of high quality colostrum. Moreover, this adequate serum IgG concentration confirms that the $\mathrm{C}$-section commonly performed in the $\mathrm{BB}$ breed is associated with a good vitality of calves at birth. The IgG serum concentration did not differ significantly between the treated and the control groups of the three farms, probably because the amount of specific IgG $(6 \mathrm{~g})$ provided by Locatim was negligible in comparison with the amount of IgG $( \pm 180 \mathrm{~g})$ provided by colostrum. The effect of Locatim could possibly be highlighted with a colostrum containing less IgG.

\section{Specific IgG Transfer}

Contrary to the study of [24] performed with the same lactoserum, the effect of Locatim is only significant for the CS31A strain in our study. This lack of significant effect for the 3 other $E$. coli strains could be attributed to a high level of specific antibodies in colostrum, likely related to a high prevalence of these strains in the three farms. 
For example, the antibody titer for the K99 strain is much higher than the titer of 0.7 found by [25]. To our knowledge, no similar data are available for the F17, F41 and CS31A antibodies titers. Nevertheless, these $4 \mathrm{E}$. coli strains are commensal bacteria for the adult cow [26] and they normally do not induce the production of antibodies. The reasons of this high level of specific antibodies are yet unclear. One possible explanation might be the neonatal infection of these animals when they were receptive to these $E$. coli strains. The K99 antibody titer in our study seems to be protective against K99 colibacillosis. Indeed, in a previous study [27], have found that calves with an antibody titer of more than 0.9 were protected from an experimental ETEC infection.

\section{CONCLUSION}

The use of the concentrated lactoserum Locatim could be justified in farms where total or partial FPT frequently occurs or when a specific IgG not present in the colostrum is needed. The significantly higher titer of CS31A antibodies in treated calves justifies the Locatim use when this specific antibody is deficient in the colostrum. The effect of such concentrated lactoserum may be not significant when passive transfer of the colostral immunity is successful. Moreover, in this study, the high incidence of $C$. parvum and the low activity of colostral antibodies against this pathogen, despite a good IgG transfer, may interfere with the Locatim's efficacy for reducing diarrhoea. Finally, further studies are needed for a better understanding of high natural antibodies levels against some $E$. coli strains observed in this study.

\section{ACKNOWLEDGEMENTS}

The authors thank the farmers and the veterinarians for their active participation in the study. We specially thank the laboratory of Loncin for field data concerning the prevalence of different enteropathogens.

\section{REFERENCES}

[1] Mellor DJ, Stafford KJ. Animal welfare implications of neonatal mortality and morbidity in farm animals. Vet J 2004; 168: 118-33.

[2] Besser TE, Gay CC, Pritchett LC. Comparison of three methods of feeding colostrum to dairy calves. J Am Vet Med 1991; 198: 41922.

[3] Clement JC, King ME, Salman MD, Wittum TE, Casper HH, Odde KG. Use of epidemiologic principles to identify risk factors associated with the development of diarrhoea in calves in five beef herds. J Am Vet Med Assoc 1995; 207: 1334-8.

[4] Quigley JD, Martin KR, Bemis DA, et al. Effects of housing and colostrum feeding on serum immunoglobulins, growth and fecal scores of Jersey calves. J Dairy Sci 1995; 78: 893-901.

[5] Busato A, Steiner L, Martin SW, Shoukri MM, Gaillard C. Calf health in cow-calf herds in Switzerland. Prev Vet Med 1997; 30: 922.

[6] Snodgrass DR, Terzolo HR, Sherwood D, Campbell I, Menzies JD, Synge BA. Aetiology of diarrhoea in young calves. Vet Rec 1986; 119: 31-4.
[7] Quigley JD, Drewry JJ. Symposium: practical considerations of transition cow and calf management, nutrient and immunity transfer from cow to calf pre- and postcalving. J Dairy Sci 1998; 81: 2779-90.

[8] Besser TE, Gay CG. The importance of colostrum to the health of neonatal calf. Vet Clin North Am 1994; 10: 107-17.

[9] Contrepois GM, Girardeau JP. Additive protective effects of colostral antipili antibodies in calves experimentally infected with enterotoxigenic Escherichia coli. Infect Immun 1985; 50: 947-9.

[10] Mee JF. The role of micronutrients in bovine periparturient problems. Cattle Practice 2004; 12(2): 95-108.

[11] Enjalbert F. The relationship between trace elements status and health in calves. Rev Vet Med 2009; 160(8-9): 429-35.

[12] Quillet JM, Assié S, Ogier de Beaulny M, Lepeule J, Seegers H. Gastro-entérites néonatales : les agents pathogènes mis en évidence dans les troupeaux bovins de Vendée. Le nouveau praticien vétérinaire élevages et santé 2007; 159(1): 313-6.

[13] De la Fuente R, Garcia A, Ruiz-Santa-Quiteria JA, et al. Proportional morbidity rates of enteropathogens among diarrheic calves in central Spain. Prev Vet Med 1998; 36(2): 145-52.

[14] Gulliksen SM, Jor E, Lie KI, et al. Enteropathogens and risk factors for diarrhea in Norwegian dairy calves. J Dairy Sci 2009; 92: 5057-66.

[15] Uhde FL, Kaufmann T, Sager H, et al. Prevalence of four enteropathogens in the faeces of young diarrhoeic calves in Switzerland. Vet Rec 2008; 163: 362-6.

[16] Trotz-William LA, Martin SW, Leslie KE, Duffield T, Nydam DV, Peregrine AS. Calf-level risk factor for neonatal diarrhea and shedding of Cryptosporidium parvum in Ontario dairy calves. Prev Vet Med 2007; 82: 12-28.

[17] Garcia A, Ruiz-Santa-Quiteria JA, Orden JA et al. Rotavirus and concurrent infections with other enteropathogens in neonatal diarrheic dairy calves in Spain. Comp Immunol Microbiol Infect Dis 2000; 23: 175-83.

[18] Reynolds DJ, Morgan JH, Chanter N, et al. Microbiology of calf diarrhoea in southern Britain. Vet Rec 1986; 119: 34-9.

[19] Guy MA, McFadden TB, Cockrell DC, Besser TE. Regulation of colostrum formation in beef and dairy cows. J Dairy Sci 1994; 77 : 3002-3007.

[20] Kruse V. Absorption of immunoglobulin from colostrum in newborn calves. Anim Prod 1970; 12: 627-38.

[21] Weaver DM, Tyler JW, VanMetre DC, Hostetler DE, Barrington G. Passive transfer of colostral immunoglobulins in calves. J Vet Intern Med 2000; 14: 569-77.

[22] Arthington JD, Cattell MB, Quigley JD, McCoy GC, Hurley WL. Passive immunoglobulin transfer in newborn calves fed colostrum or spray-dried serum protein alone or as a supplement to colostrum of varying quality. J Dairy Sci 2000; 83: 2834-8.

[23] Mc Guire TM, Adams SA. Failure of colostral immunoglobulin transfer to calves: prevalence and diagnosis. Cont Educ 1982; 4: s35-s39.

[24] Pravieux JJ, Bohy A, Charrier E, Mathevet P. Le transfert colostral : données terrain en troupeaux allaitants et évaluation de l'apport d'un sérocolostrum. In: Proceedings of the Journée Bovine Nantaise, 2006; pp. 79-80.

[25] Kohara J, Hirai T, Mori K, Ishizaki H, Tsunemitsu H. Enhancement of passive immunity with maternal vaccine against newborn calf diarrhea. J Vet Med Sci 1997; 59: 1023-5.

[26] Mainil J. Updating on enteric colibacillosis in calves. Ann Med Vet 2000; 144: 121-36.

[27] Ohashi S, Shiba F, Haga Y, et al. Passive immunizing effect of neonatal calves by vaccinating dams with Escherichia coli bacterin containing K99 antigen against experimental colibacillosis. Bull Nippon Vet Zootech Coll 1990; 39: 40-49. 